\title{
Korelasi Antara Sikap Tanggung Jawab dalam Menyelesaikan Tugas-Tugas dengan Kompetensi Pengetahuan IPS
}

\author{
I.Gst. A. Candra Dewi ${ }^{1 *}$, I Wyn. Sujana² ${ }^{2}$ Ni Wyn. Suniasih ${ }^{3}$
}

123Jurusan Pendidikan Guru Sekolah Dasar, FIP, Universitas Pendidikan Ganesha, Indonesia

\author{
A R T I C LEINFO \\ Article history: \\ Received 01 Desember \\ 2018 \\ Received in revised form \\ 30 Desember 2018 \\ Accepted 15 Januari 2019 \\ Available online 20 \\ Februari 2019

\section{Kata Kunci:} \\ Sikap Tanggung Jawab, \\ Kompetensi Pengetahuan \\ IPS \\ Keywords: \\ Attitude of Responsibility, \\ Knowledge Competence of \\ IPS
}

\begin{abstract}
A B S T R A K
Penelitian ini bertujuan untuk mengetahui korelasi yang signifikan antara sikap tanggung jawab dalam menyelesaikan tugastugas dengan kompetensi pengetahuan IPS siswa kelas V SD Gugus Kapten Kompyang Sujana Tahun Pelajaran 2017/2018. Jenis penelitian ini adalah penelitian ex post facto dengan korelasi yang bersifat asimetris. Populasi dari penelitian ini merupakan siswa kelas V SD Gugus Kapten Kompyang Sujana Tahun Pelajaran 2017/2018 yang memiliki populasi 637 orang. Penentuan sampel menggunakan teknik proporsional random sampling dengan taraf kesalahan $5 \%$ dan diperoleh banyak sampel dari populasi adalah 227 orang. Data diperoleh melalui metode pencatatan dokumen kompetensi pengetahuan IPS dan angket sikap tanggung jawab dalam menyelesaikan tugas-tugas. Dalam penelitian ini data yang terkumpul dianalisis menggunakan analisis korelasi product momentyang sebelumnya data diuji normalitas sebaran data sebagai prasyarat analisis. Berdasarkan hasil analisis dapat disimpulkan bahwa terdapat korelasi yang signifikan antara sikap tanggung jawab dalam meyelesaikan tugas-tugas dengan kompetensi pengetahuan IPS siswa kelas V SD Gugus Kapten Kompyang Sujana Tahun Pelajaran 2017/2018, dengan arah korelasi positif, artinya semakin tinggi sikap tanggung jawab siswa dalam menyelesaikan tugas-tugas maka semakin tinggi pula kompetensi pengetahuan IPS yang diperoleh siswa.
\end{abstract}

\section{A B S T R A C T}

This study aims to find out a significant correlation between the attitude of responsibility in completing tasks with IPS knowledge competency in fifth grade students of SD Gugus Kapten Kompyang Sujana 2017/2018 Academic Year. This type of research is ex post facto research with asymmetric correlations. The population of this study were fifth grade students of SD Gugus Kapten Kompyang Sujana 2017/2018 Academic Year which had a population of 637 people. Determination of the sample using proportional random sampling technique with a level of error of $5 \%$ and obtained many samples from the population is 227 people. Data is obtained through the method of recording IPS knowledge competency documents and questionnaires on responsibility in completing tasks. In this study the collected data were analyzed using product moment correlation analysis which previously tested the data distribution normality as a prerequisite for analysis. Based on the results of the analysis it can be concluded that there is a significant correlation between the attitude of responsibility in completing tasks with the IPS knowledge competency of the fifth grade students of SD Gugus Kapyang Kompyang Sujana 2017/2018 Academic Year, with the direction of positive correlation, meaning the higher the students' responsibility in completing assignments the higher the IPS knowledge competency obtained by students.

\footnotetext{
${ }^{1}$ Corresponding author.

E-mail addresses: gusti.ayu.candra@undiksha.ac.id (I.Gst. A. Candra Dewi)
} 


\section{Pendahuluan}

Pendidikan merupakan kebutuhan primer bagi manusia yang selalu mengalami perubahan, dan perbaikan sesuai dengan perkembangan disegala bidang kehidupan. Upaya perubahan dan perbaikan tersebut bertujuan membawa kualitas pendidikan di Indonesia menjadi lebih baik. Perubahan dan perbaikan dalam bidang pendidikan meliputi berbagai komponen yang terlibat didalamnya, baik itu pelaksana pendidikan di lapangan (kompetensi guru dan kualitas tenaga pendidik), mutu pendidikan, perangkat kurikulum, sarana dan prasarana pendidikan dan mutu manejemen pendidikan termasuk perubahan dalam metode dan strategi pembelajaran yang lebih inovatif. Salah satu komponen dalam bidang pendidikan yang saat ini sedang mengalami perubahan dan perbaikan adalah kurikulum.

Kurikulum merupakan suatu alat yang sangat penting bagi pencapaian keberhasilan pendidikan. Tanpa adanya kurikulum yang tepat dan sesuai, maka tujuan dari pendidikan menjadi tidak optimal. "Kurikulum adalah seperangkat rencana dan pengaturan mengenai tujuan, isi, dan bahan pelajaran serta cara yang digunakan sebagai pedoman penyelenggaraan kegiatan pembelajaran untuk mencapai tujuan pendidikan tertentu" (Kurniasih dan Sani, 2014:2). Kurikulum yang serentak diterapkan hampir diseluruh sekolah pada jenjang SD, SMP dan SMA/K di Denpasar, Bali adalah kurikulum 2013.

Kurikulum 2013 lebih menekankan pada kompetensi dengan pemikiran kompetensi berbasis sikap, keterampilan, dan pengetahuan. Penekanan kurikulum 2013 memerlukan perubahan paradigma pembelajaran dengan melatih siswa untuk belajar mengobservasi, mengajukan pertanyaan, mengumpulkan data, menganalisis data, dan mengkomunikasikan hasil belajar. Pembelajaran yang dirancang dalam kurikulum 2013 disebut dengan pembelajaran tematik.

Pembelajaran tematik adalah pembelajaran yang digunakan dalam satu kali pembelajaran, yang berisi beberapa muatan materi pembelajaran yang dikaitkan dalam satu tema. Pembelajaran tematik menekankan pada keterlibatan siswa secara aktif dalam proses pembelajaran, sehingga siswa dapat memperoleh pengalaman langsung dan terlatih untuk dapat menemukan sendiri berbagai pengetahuan yang dipelajarinya. Pembelajaran tematik lebih menekankan pada penerapan konsep belajar sambil melakukan sesuatu (learning by doing). Selain itu, penerapan pembelajaran tematik di sekolah dasar akan sangat membantu siswa dalam berpikir dan membentuk tingkah lakunya sehingga siswa mengalami peningkatan pada sikap dan kompetensi pengetahuannya.

Supardi (2015:152) "kompetensi pengetahuan merupakan kegiatan pembelajaran yang menuntut kemampuan berpikir mulai dari yang paling sederhana hanya sekedar tahu sampai kepada yang paling kompleks yaitu memberikan penilaian tentang sesuatu baik atau buruk, benar atau salah, bermanfaat atau tidak bermanfaat". Kompetensi pengetahuan juga dapat dinyatakan sebagai kompetensi pada ranah kognitif yang mampu mengukur tingkat penguasaan atau pencapaian siswa dalam aspek pengetahuan (Kosasih 2014). Kompetensi pengetahuan bergantung pada efikasi diri siswa yang baik dan salah satu bentuk efikasi diri yang dimiliki oleh siswa adalah sikap tanggung jawab.

Menurut Fadillah \& Lilif (2013:205) "tanggung jawab adalah sikap dan perilaku seseorang untuk melaksanakan tugas dan kewajibannya, yang seharusnya dia lakukan, terhadap diri sendiri, masyarakat, lingkungan (alam, sosial, dan budaya), negara dan Tuhan Yang Maha Esa". Sikap tanggung jawab diperlukan siswa pada proses pembelajaran, sehingga setiap siswa dapat menyadari dan melaksanakan apa yang sudah ditugaskan kepadanya dengan sebaik-baiknya agar mencapai hasil yang maksimal. Salah satu bentuk taggung jawab siswa yang dapat dilihat dengan jelas adalah mengerjakan tugas-tugas yang diberikan oleh guru seperti membuat tugas rumah (PR) yang dikerjakan di rumah, bukan di sekolah serta dikerjakan dengan tekun. Sehingga pada saat diadakan tes, siswa sudah mengerti dengan bahan ajar dan dapat mejawab soal tes dengan baik. Siswa yang membuat tugas-tugas sekolah dengan baik, maka akan mendapatkan output (kompetensi pengetahuan) yang lebih tinggi dibandingkan dengan siswa yang mengerjakan tugas secara tidak serius (Zimmerman et al., 2005).Sikap tanggung jawab yang dimiliki siswa dapat dilihat padaoutput (kompetensi pengetahuan) yang maksimal dalam suatu mata pelajaran (Zimmerman et al., 2005),salah satu mata pelajaran yang dipelajari disekolah dasar adalah mata pelajaran IPS.

IPS adalah mata pelajaran yang mempelajari, menelaah, menganalisis gejala dan peristiwa dalam masalah sosial di masyarakat dengan meninjau dari berbagai aspek kehidupan atau satu perpaduan. Menurut Susanto (2013) Ilmu Pengetahuan Sosial (IPS) merupakan integrasi dari berbagai ilmu-ilmu sosial dan humaniora, yaitu: sosiologi, sejarah geografi, ekonomi, politik, hukum, dan budaya. Tujuan pendidikan IPS pada intinya diarahkan pada proses pengembangan siswa agar peka terhadap masalah sosial yang terjadi di masyarakat, memiliki sikap mental positif terhadap perbaikan segala ketimpangan yang terjadi, dan terampil mengatasi setiap masalah yang terjadi sehari-hari, baik yang menimpa dirinya sendiri maupun yang menimpa masyarakat. Trianto (2010:176) menyatakan bahwa "tujuan utama IPS 
ialah untuk mengembangkan potensi siswa agar peka terhadap masalah sosial yang terjadi di masyarakat, memiliki sikap mental positif, terampil mengatasi setiap masalah yang terjadi sehari-hari".

Salah satu masalah yang mendasar yang dihadapi saat ini adalah masih rendahnya kompetensi pengetahuan siswa, khususnya pada mata pelajaran IPS. Hal ini terjadi pada mata pelajaran IPS di kelas V SD Gugus Kapten Kompyang Sujana. Berdasarkan observasi yang dilakukan peneliti di kelas V SD Gugus Kapten Kompyang Sujana khususnya pada mata pelajaran IPS, diperoleh data dari seluruh siswa kelas V di SD Gugus Kapten Kompyang Sujana masih banyak siswa yang nilai kompetensi pengetahuan IPS masih perlu ditingkatkan.

Berdasarkan hasil wawancara dengan salah satu guru wali kelas $\mathrm{V}$, beliau mengungkapkan bahwa ketika proses pembelajaran sedang berlangsung banyak siswa yang gaduh dikelas, malas mengerjakan tugas rumah, dan menyalin pekerjaan teman yang diduga disebabkan kurangnya tanggung jawab siswa.Dari hasil wawancara dan observasi, diduga rendahnya tanggung jawab siswa kelas V SD Gugus Kapten Kompyang Sujana memiliki korelasi dengan kompetensi pengetahuan IPS siswa.

Tujuan dari penelitian ini untuk mengetahui korelasi yang signifikan antara sikap tanggung jawab dalam menyelesaikan tugas-tugas dengan kompetensi pengetahuan IPS siswa Kelas V SD Gugus Kapten Kompyang Sujana Tahun Pelajaran 2017/2018.

\section{Metode}

Jenis penelitian ini adalah peneliian ex post facto dengan studi korelasional. Penelitian ini dilaksanakan pada siswa kelas V SD Gugus Kapten Kompyang Sujana Tahun Pelajaran 2017/2018 yang terdiri dari 7 sekolah negeri dan 1 sekolah swasta. SD yang dipergunakan dalam penelitian ini yaitu seluruh sekolah negeri di SD Gugus Kapten Kompyang Sujana. Letak masing-masing SD di Gugus Kapten Kompyang Sujana cukup berdekatan. Ketujuh sekolah yaitu SD Negeri 1 Padangsambian,SD Negeri 2 Padangsambian, SD Negeri 8 Padangsambian, SDNegeri 9 Padangsambian, SD Negeri 10 Padangsambian, SD Negeri 12 Padangsambian dan SD Negeri 14 Padangsambian.

Dalam penentuan sampel dapat dilihat dari jumlah populasi siswa di SD Gugus Kapten Kompyang Sujana, lalu di bandingkan pada pada tabel Issac and Michael. Dalam tabel tersebut dijelaskan tentang besarnya sampel yang diambil dari populasi dengan tingkat signifikansi 1\%, 5\%, dan 10\%. Sesuai dengan tabel tersebut, jumlah populasi di SD Gugus Kapten Kompyang Sujana sebanyak 637 siswa, sedangkan populasi yang ada dalam tabel Issac and Michael yang mendekati jumlah populasi di SD Gugus Kapten Kompyang Sujana adalah 650 orang, jadi jumlah sampel yang diambil dengan tingkat signifikansi 5\% adalah 227 orang.

Jadi dapat disimpulkan bahwa penelitian ini menggunakan populasi 637 siswa dan sampel 227 siswa. Dalam pengambilan sampel digunakan teknik proporsional random sampling. Cara penentuan sampel secara random dilakukan dengan menggunakan undian nomor absen siswa yang melibatkan masing-masing wali kelas $\mathrm{V}$ untuk mengambil undian tersebut sebanyak sampel yang diminta pada tiaptiap sekolah.

Variabel bebas yang ditetapkan dalam penelitian ini adalah sikap tanggung jawab dalam menyelesaikan tugas-tugas, sedangkan variabel terikat dalam variabel ini adalah kompetensi pengetahuan IPS. Pengumpulan data dalam penelitian ini meliputi: (1) sikap tanggung jawab dalam menyelesaikan tugas-tugas, dan (2) kompetensi pengetahuan IPS. Data sikap tanggung jawab dalam menyelesaikan tugastugas dikumpukan menggunakan kuesioner. Kuesioner tersebut terdapat pernyataan dengan masingmasing 4 pilihan jawaban yaitu Sangat Setuju (SS), Setuju (S), Tidak Setuju (TS) dan Sangat Tidak Setuju (STS). Pernyataan yang terdapat pada kuesioner sebanyak 30 pernyataan yang terdiri dari pernyataan positif dan negatif. Pernyataan positif merupakan pernyataan yang mendukung komponen sikap tanggung jawab dalam menyelesaikan tugas-tugas. Sedangkan pernyataan negatif merupakan pernyataan yang tidak mendukung komponen sikap tanggung jawab dalam menyelesaikan tugas-tugas.

Data kompetensi pengetahuan IPS siswa diperoleh melalui pencatatan dokumen. Data yang dikumpulkan melalui teknik pengumpulan data yang diperoleh dari istrumen tes yang sudah dibuat oleh masing-masing wali kelas $\mathrm{V}$ yang sudah berpedoman pada kompetensi dasar dan indiktor pada buku tematik tema 7 siswa kelas $V$, sehingga yang dicari hanya hasil dari tes tesebut.

Pengujian instrumen sikap tanggung jawab dalam menyelesaikan tugas-tugas menggunakan uji validitas logis yang terdiri dari validitas isi dan validitas konstruk serta uji validitas empirik. Uji validitas isi dilakukan dengan cara menyesuaikan butir tes dengan indikator. Uji validitas isi ini dilakukan dengan membuat kisi-kisi pernyataan. Menguji validitas konstrak, dapat digunakan pendapat dari para ahli (judgment experts). Setelah instrument dikonstruksi tentang aspek-aspek yang diukur dengan dilandaskan teori tertentu, hasil tersebut dikonstruksikan kepada para ahli. Setelah melalui proses review oleh ahli, instrumen mengalami perbaikan sesuai saran ahli.Kemudian dilanjutkan dengan validitas empiris dari 
skor angket dan data responden terhadap butir soal dengan menggunakan korelasi product moment yang dikemukaka oleh Pearson.

Selain uji validitas, syarat lainnya adalah uji reliabilitas. Suatu tes dikatakan memiliki reliabilitas tinggi, jika tes tersebut dapat memberikan hasil yang tetap (ajeg). Untuk mengukur tingkat keajegan soal digunakan rumus KoefisienAlpha-Cronbach karena tes bersifat politomi.

Langkah-langkah dalam menguji reliabilitas soal kuesioner sikap tanggung jawab dalam menyelesaikan tugas-tugas adalah (1) menghitung varian tiap butir tes, (2) menghitung varian total, (3) menghitung nilai reliabilitas.Jika nilai alpha sama dengan atau lebih besar daripada 0,70 berarti instrumen yang sedang diuji realibilitasnya dinyatakan telah reliabel. Apabila nilai alpha lebih kecil daripada 0,70 berarti instrumen yang sedang diuji realibilitasnya dinyatakan unreliabel.

Berdasarkan hasil perhitungan terhadap 31 butir tes yang dinyatakan valid maka diperoleh nilai alpha $=0,93$. Berdasarkan hal tersebut, maka nilai alpha $>0,70$ yang berarti instrumen angket sikap tanggung jawab dalam menyelesaikan tugas-tugas pada penelitian ini tergolong reliabel.

Teknik analisis data dalam penelitian ini yaitu analisis statistik deskriptif dan analisis statistik inferensial. Analisis statistik deskriptif menggunakan rata-rata (mean) dan standar deviasi. Sedangkan analisis statistik inferensial menggunakan teknik korelasi product moment. Sebelum menguji hipotesis, maka dilakukan uji prasyarat yaitu uji normalitas. Uji normalitas $\left(\mathrm{X}^{2}\right)$ untuk mengetahui apakah data berdistribusi normal atau tidak. Hasil $\mathrm{X}^{2}$, selanjutnya dikonsultasikan ke tabel chi-square pada taraf signifikansi $5 \%$ dan derajat kebebasan $(\mathrm{dk})=\mathrm{k}-1$, dengan $\mathrm{k}$ adalah banyaknya kelas atau kelompok interval (Supardi, 2016).

Kreteria yang digunakan dengan menggunakan taraf signifikan $5 \%$, jika nilai $X^{2}$ hitung $\leq X^{2}$ tabel maka $H_{0}$ diterima dan $H_{a}$ ditolak yang berarti sebaran data berdistribusi normal, sedangkan jika nilai $\mathrm{X}^{2}{ }_{\text {hitung }}>$ $\mathrm{X}^{2}$ tabel maka $H_{0}$ ditolak dan $H_{a}$ diterima yang berarti sebaran data tidak berdistribusi normal (Sugiyono, 2016).

Adapun hipotesis yang diuji yaitu hipotesis nol $\left(H_{0}\right)$ yang berbunyi tidak terdapat korelasi yang signifikan antara sikap tanggung jawab dalam menyelesaikan tugas-tugas dengan kompetensi pengetahuan IPS siswa kelas V SD Gugus Kapten Kompyang Sujana Tahun Pelajaran 2017/2018. Ketentuan dari analisis product moment yang digunakan yaitu apabila hasil $r_{x y \text { hitung }}>r_{x y \text { tabel }}$ maka $H_{0}$ ditolak dan hipotesis alternatif $\left(H_{a}\right)$ diterima. Sebaliknya apabila hasil $r_{x y \text { hitung }} \leq r_{x y \text { tabal }}$ maka $H_{0}$ ditolak dan $H_{a}$ diterima. Nilai $r_{x y \text { tabel }}$ pada taraf signifikansi $5 \%$ adalah 0,138 sebagai pembanding.

\section{Hasil dan Pembahasan}

Berdasarkan hasil analisis data sikap tanggung jawab dalam menyelesaikan tugas-tugas diketahui bahwa Xt = 94 dan $\mathrm{Xr}=57$. Hasil perhitungan distribusi frekuensi memperoleh hasil banyak kelas interval setelah dibulatkan menjadi 9 kelas interval dan panjang kelas setelah dibulatkan menjadi 5.Dari data tersebut dapat dilihat dalam bentuk grafik sebagai berikut.

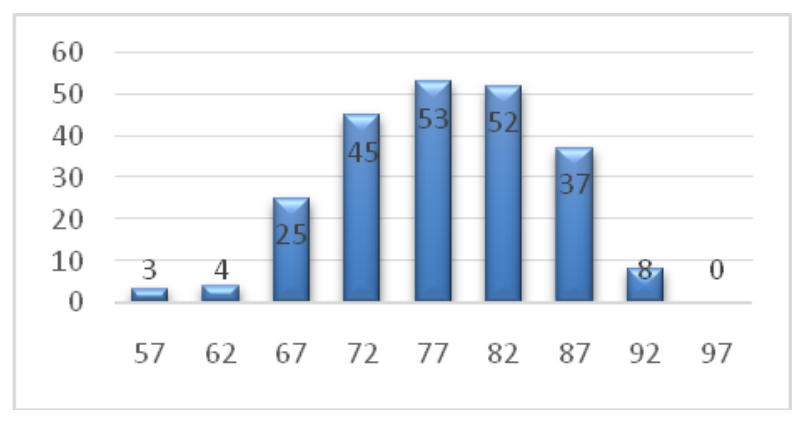

Gambar 1. Histogram Data Sikap Tanggung Jawab

Berdasarkan histogram data nilai sikap tanggung jawab dalam menyelesaikan tugas-tugas dapat diketahui bahwa nilai terbanyak terdapat pada interval ke-5. Tingkat tanggung jawab yang diperoleh siswa hasilnya akan dikonversikan dengan cara membandingkan angka frekuensi relatif dengan kriteria penilaian acuan patokan (PAP) skala 5.

Berdasarkan kategori tingkat tanggung jawab dalam menyelesaikan tugas-tugas serta hasil dari analisis data diperoleh $1 \%$ dari jumlah siswa 227 sikap tanggung jawabdalam menyelesaikan tugas-tugas 
berada pada kategori sangat kurang baik, 2\% pada kategori kurang baik, 54\% pada kategori cukup baik, $39 \%$ pada kategori baik, $4 \%$ pada kategori sangat baik.

Hasil uji prasyarat analisis data, diperoleh bahwa data sikap tanggung jawab dalam menyelesaikan tugas-tugas yaitu $x^{2}{ }_{\text {hitung }}=10,64$ dan menggunakan taraf signifikansi $5 \%$ dengan derajat kebebasan 5 , maka diperoleh $x^{2}{ }_{\text {tabel }}=11,07$. Hal ini berarti $\mathrm{x}^{2}$ hitung $=10,64 \leq \mathrm{x}^{2}$ tabel $=11,07$ yang berarti sebaran data berdistribusi normal.

Hasil analisis data nilai kompetensi pengetahuan IPS diketahui bahwa Xt $=95$ dan $\mathrm{Xr}=50$. Hasil perhitungan distribusi frekuensi memperoleh hasil banyak kelas interval setelah dibulatkan menjadi 9 kelas interval dan panjang kelas setelah dibulatkan menjadi 6.Dari data tersebut dapat juga dilihat dalam bentuk grafik sebagai berikut.

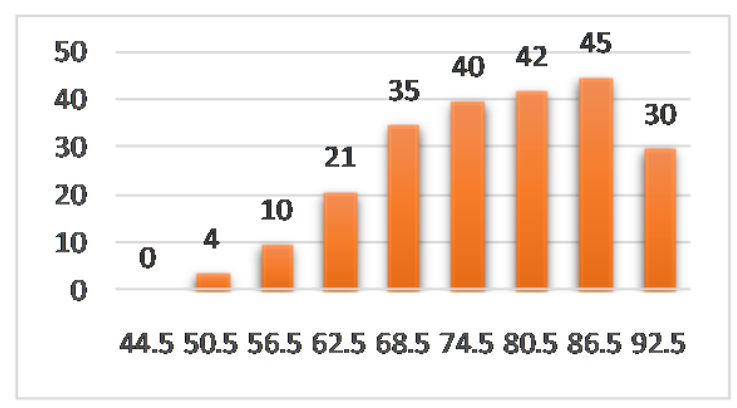

Gambar 2. Histogram Data Kompetensi Pengetahuan IPS

Berdasarkan histogram data kompetensi pengetahuan IPS dapatdiketahui bahwa nilai terbanyak terdapat pada interval ke-8. Kompetensi pengetahuan IPS yang diperoleh anak hasilnya dikonversikan dengan cara membandingkan angka frekuensi relatif dengan kriteria penilaian acuan patokan (PAP) skala 5.

Berdasarkan kategori kompetensi pengetahuan IPS serta hasil dari analisis data maka diperoleh 2\% dari jumlah siswa 227 nilai kompetensi pengetahuan IPSnya berada pada kategori sangat kurang baik, $12 \%$ pada kategori kurang baik, 36\% pada kategori cukup baik, $37 \%$ pada kategori baik, $13 \%$ pada kategori sangat baik.

Hasil uji prasyarat analisis data, diperoleh bahwa data kompetensi pengetahuan IPS siswa yaitu $x^{2}{ }_{\text {hitung }}=7,03$ dan menggunakan taraf signifikansi 5\% dengan derajat kebebasan 5, maka diperoleh $x^{2}$ tabel $=11,07$. Hal ini berarti $x^{2}$ hitung $=7,03 \leq x^{2}$ tabel $=11,07$ yang berarti sebaran data berdistribusi normal.

Setelah data diketahui berdistribusi normal, dilanjutkan dengan pengujian hipotesis penelitian. Pengujian hipoteisis yang digunakan adalah analisis product moment, untuk mengetahui korelasi antara sikap tanggung jawab dalam menyelesaikan tugas-tugas dengan kompetensi pengetahuan IPS. Berdasarkan pada tabel kerja, maka diperoleh nilai untuk menghitung koefisien korelasi sebagai berikut.

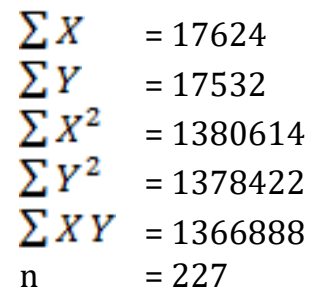

Setelah mendapatkan nilai tersebut, maka nilai-nilai tersebut dimasukkan ke dalam rumus product moment sebagai berikut.

$$
r_{x y}=\frac{\mathrm{N} \sum \mathrm{XY}-\left(\sum \mathrm{x}\right)(\Sigma \mathrm{Y})}{\sqrt{\left[\mathrm{N} \sum \mathrm{X}^{2}-\left(\sum \mathrm{X}\right)^{2}\right]\left[\mathrm{N} \sum \mathrm{Y}^{2}-\left(\sum \mathrm{Y}\right)^{2}\right]}}
$$

(Agung, 2016:125)

Keterangan:

$$
\begin{array}{ll}
r_{x y} & =\text { Koefisien korelasi } \\
\mathrm{N} & =\text { Jumlah subjek }
\end{array}
$$




$\begin{array}{ll}\mathrm{X} & =\text { Skor item } \\ \mathrm{Y} & =\text { Skor total } \\ \sum \mathrm{X} & =\text { Jumlah skor item } \\ \sum \mathrm{Y} & =\text { Jumlah skor total } \\ \sum \mathrm{X}^{2} & =\text { Jumlah kuadrat skor item } \\ \sum \mathrm{Y}^{2} & =\text { Jumlah kuadrat skor total }\end{array}$

Setelah dilakukan pengujian signifikansi koefisien dengan rumus product moment diperoleh hasil $r_{x y \text { hitung }}=0,331$. Untuk uji signifikansi koefisien korelasi, digunakan taraf signifikansi 5\% pada nilai tabel product moment (r) untuk $\mathrm{n}=227$. Nilai $r_{x y \text { tabel }}=0,138$. Maka dapat dinyatakan $r_{x y \text { hitung }}=0,331>r_{x y \text { tabel }}=0,138$, sehingga $H_{0}$ yang berbunyi tidak terdapat korelasi yang signifikan antara sikap tanggung jawab dalam menyelesaikan tugas-tugas dengan kompetensi pengetahuan IPS siswa kelas V SD Gugus Kapten Kompyang Sujana Tahun Pelajaran 2017/2018 ditolak, dan $H_{a}$ diterima. Hal ini menunjukkan bahwa terdapat korelasi antara sikap tanggung jawab dalam menyelesaikan tugas-tugas dengan kompetensi pengetahuan IPS. Sedangkan arah korelasi yang diperoleh yaitu arah korelasi positif yang berarti semakin tinggi sikap tanggung jawab siswa dalam menyelesaikan tugas-tugas maka semakin tinggi pula kompetensi pengetahuan IPS yang diperoleh siswa.

Berdasarkan hasil analisis yang diperoleh arti $r_{x y \text { hitung }}>r_{x y t a b e l}$ sehingga $H_{a}$ yang berbunyi terdapat korelasi yang signifikan antara sikap tanggung jawab dalam menyelesaikan tugas-tugas dengan kompetensi pengetahuan IPS siswa kelas V SD Gugus Kapten Kompyang Sujana Tahun Pelajaran 2017/2018 diterima. Berdasarkan uraian tersebut dapat diinterpretasi, bahwa rata-rata siswa yang mempunyai sikap tanggung jawab dalam menyelesaikan tugas-tugas dapat memperoleh kompetensi pengetahuan IPS yang lebih tinggi daripada siswa yang tidak mempunyai dan mengembangkan sikap tanggung jawab dalam menyelesaikan tugas-tugas.

Interpretasi di atas dapat diartikan bahwa, semakin tinggi sikap tanggung jawab dalam menyelesaikan tugas-tugas dapat membuat siswa memperoleh kompetensi pengetahuan lebih baik terutama pada mata pelajaran IPS. Hal ini sesuai dengan pendapat Zimmerman et al. (2005)sikap tanggung jawab yang dimiliki siswa dapat dilihat pada output (kompetensi pengetahuan) yang maksimal dalam suatu mata pelajaran.

Bentuk tanggung jawab siswa dalam menyelesaikan tugas-tugas mata pelajaran IPS yang diberikan oleh guru dengan baik dan sungguh-sungguh, dapat menyebabkan siswa mengerti dengan bahan ajar dan dapat mejawab soal ulangan IPS tersebut dengan baik. Setiap siswa harus menanamkan rasa tanggung jawab pada diri masing-masing, karena tanggung jawab merupakan salah satu kunci penting untuk mencapai tujuan belajar. Terdapat enam karakteristik yang membentuk prilaku tanggung jawab siswa, karakteristik-karakteristik tersebut antara lain; melakukan sesuatu yang seharusnya dilakukan, selalu menunjukkan ketekunan, kerajinan dan terus berusaha, selalu melakukan yang terbaik untuk dirinya dan orang lain, selalu disiplin dan mengontrol diri dalam keadaan apapun, selalu mengkaji, menelaah dan berpikir sebelum bertindak, mempertimbangkan dan memperhitungkan semua konsekuensi dari perbuatan.

Karakteristik-karakteristik tanggung jawab tersebut perlu dimiliki dan ditanam pada saat siswa mengikuti pembelajaran, terutama pada saat mengerjakan tugas-tugasnya. Apabila keenam karakteristik tersebut telah ada pada diri siswa maka, siswa akan menjadi lebih bertanggung jawab dalam mengerjakan tugas-tugas yang diberikan. Siswa yang membuat tugas-tugas sekolah dengan baik, maka siswa tersebut akan mendapatkan output (kompetensi pengetahuan) yang lebih tinggi dibandingkan dengan siswa yang mengerjakan tugas secara tidak serius.

Hal tersebut sejalan dengan hasil penelitian yang dilakukan oleh Yeni Setyowati (FKIP, Universitas Muhammadiyah Surakarta, 2013) tentang pengaruh motivasi dan tanggung jawab belajar siswa terhadap prestasi belajar matematika, hasil penelitiannya memperlihatkan tanggung jawab belajar secara parsial berpengaruh signifikan terhadap prestasi belajar matematika pada siswa Kelas VIII SMP Negeri 3 Sragen Tahun Ajaran 2012/2013. Berdasarkan hal tersebut maka, kompetensi pengetahuan ditentukan oleh tingginya sikap tanggung jawab dalam menyelesaikan tugas-tugas sehingga dapat berkontribusi terhadap kompetensi pengetahuan siswa.

Pada penelitian ini diperoleh $r_{x y \text { hitung }}=0,331$ dengan $r_{x y \text { tabel }}=0,138$ yang berarti $r_{x y \text { hitung }}$ $=0,331>r_{x y \text { tabel }}=0,138$. Dengan lebih besarnya $r_{x y \text { hitung }}$ daripada $r_{x y \text { tabel }}$ dapat disimpulkan bahwa ada korelasi yang signifikan antara sikap tanggung jawab dalam menyelesaikan tugas-tugas dengan kompetensi pengetahuan IPS siswa kelas V SD Gugus Kapten Kompyang Sujana Tahun Pelajaran $2017 / 2018$. 


\section{Simpulan dan Saran}

Hasil analisis menunjukkan bahwa terdapat korelasi yang signifikan antara sikap tanggung jawab dalam menyelesaikan tugas-tugas dengan kompetensi pengetahuan IPS Siswa Kelas V SD Gugus Kapten Kompyang Sujana Tahun Pelajaran 2017/2018. Katagori korelasi yang diperoleh termasuk korelasi yang kuat antara sikap tanggung jawab dalam menyelesaikan tugas-tugas dengan kompetensi pengetahuan IPS. Sedangkan arah korelasi adalah positif karena nilai $r$ positif, berarti semakin tinggi sikap tanggung jawab dalam menyelesaikan tugas-tugas maka semakin meningkatkan kompetensi pengetahuan IPS siswa.

Berdasarkan hasil analisis dengan menggunakan microsoft excel dan menghitung manual yang diperoleh $r_{\text {hitung }}=0,331$ dengan $r_{\text {tabel }}$ pada taraf signifikan $5 \%$ dengan $n=227$ sehingga diperoleh $r_{\text {tabel }}=$ 0,138 yang memiliki arti $r_{\text {hitung }}=0,331>r_{\text {tabel }}=0,138$, sehingga $H_{a}$ yang berbunyi terdapat korelasi yang signifikan antara sikap tanggung jawab dalam menyelesaikan tugas-tugas dengan kompetensi pengetahuan IPS siswa Kelas V SD Gugus Kapten Kompyang Sujana Tahun Pelajaran 2017/2018 diterima.

Berdasarkan uraian tersebut dapat dikemukakan bahwa rata-rata siswa yang mempunyai sikap tanggung jawab dalam menyelesaikan tugas-tugas dapat memperoleh kompetensi pengetahuan IPS yang lebih tinggi daripada siswa yang tidak mempunyai dan mengembangkan sikap tanggung jawab dalam menyelesaikan tugas-tugas. Pengertian tersebut dapat diartikan, semakin tinggi sikap tanggung jawab dalam menyelesaikan tugas-tugas dapat membuat siswa memperoleh kompetensi pengetahuan lebih baik terutama pada mata pelajaran IPS. Jadi dapat disimpulkan bahwa korelasi antara sikap tanggung jawab dalam menyelesaikan tugas-tugas dengan kompetensi pengetahuan IPS memiliki korelasi dengan arah positif.

Berdasarkan hasil penelitian ini, maka dapat diajukan beberapa saran guna peningkatan kualitas pembelajaran yaitu:

Kepada siswa, agar memiliki sikap tanggung jawab khususnya tanggung jawab dalam menyelesaikan tugas-tugas yang diberikan kepadanya. Dengan memiliki sikap tanggung jawab dalam meyelesaikan tugas-tugas diharapkan siswa dapat memperoleh kompetensi pengetahuan yang baik pula, karena sikap tanggung jawab dalam menyelesaikan tugas-tugas memiliki korelasi dengan kompetensi pengetahuan IPS.

Kepada guru, agar mulai memperhatikan sikap tanggung jawab siswa terutama sikap tanggung jawab siswa dalam menyelesaikan tugas-tugas sekolah. Guru juga harus berusaha menumbuhkan rasa kesadaran siswa terhadap pentingnya tugas-tugas sekolah yang diberikan, selain itu guru sebagai panutan siswa diharapkan memberikan contoh serta tauladan yang baik khususnya pada sikap tanggung jawab.

Kepada sekolah, agar dapat menggunakan hasil penelitian ini sebagai pendukung sumber belajar guru dalam meningkatkan kualitas pendidikan dengan menumbuhkan sikap tanggung jawab siswa khususnya tanggung jawab dalam meyelesaikan tugas-tugas di sekolah, sehingga sekolah mampu menghasilkan siswa yang berkualitas.

Kepada peneliti lain, agar hasil penelitian ini digunakan sebagai referensi untuk melaksanakan penelitian selanjutnya dan semoga penelitian ini bermanfaat bagi seluruh elemen masyarakat yang menggunakan penelitian ini.

\section{Daftar Rujukan}

Agung, A.A.Gede. 2016. Statistika Dasar untuk Pendidikan. Yogyakarta: Deepublish.

Arikunto, Suharsimi. 2010. Prosedur Penelitian Suatu Pendekatan Praktik. Jakarta: PT Rineka Cipta.

Arikunto, Suharsimi. 2015. Dasar-Dasar Evaluasi Pendidikan. Jakarta: Bumi Aksara.

Badan Standar Nasional Pendidikan, 2006. Standar Isi Untuk Satuan Pendidikan Dasar dan Menengah: Jakarta.

Dantes, Nyoman. 2007. Metodologi Penelitian Untuk Ilmu-Ilmu Sosial dan Humaniora. Singaraja: Universitas Pendidikan Ganesha.

Darmadi, Hamid. 2014. Metode Penelitian Pendidikan dan Sosial. Bandung: Alfabeta.

Depdiknas, 2003. Undang-undang Sistem Pendidikan Nasional. Jakarta: Departemen Pendidikan Nasional. 
Emzir, 2011. Metodologi Penelitian Pendidikan Kuantitatif dan Kualitatif. Jakarta: PT Raja Grafindo Persada.

Fadillah \& Lilif, 2013. Pendidikan Karakter Anak Usia Dini. Jogjakarta: Ar-Ruzz Media.

Kosasih, E. 2014. Strategi Belajar dan Pembelajaran Implementasi Kurikulum 2013. Bandung: yrama Widya.

Kurniasih, Imas dan Berlin Sani. 2014. Sukses Mengimplementasikan Kurikulum 2013. Jakarta: Kata Pena.

Permendikbud, 2016. Peraturan Menteri Pendidikan dan Kebudayaan Republik Indonesia Nomor 20 Tahun 2016 tentang Standar Kompetensi Lulusan Pendidikan Dasar dan Menengah. Jakarta: Kementrian Pendidikan dan Kebudayaan.

Prasetyo, Sulis Nur. 2010. “Manajemen Perguruan Pancak Silat di Kabupaten Bantul”.Skripsi. Yogyakarta: FIK UNY. Tersedia pada http://eprints.uny.ac.id/15701/1/09603141018.pdf. Diakses pada tanggal 20 januari 2018.

Rahmagari, Ambar. 2014. “Hubungan Tanggung Jawab Siswa Dengan Prestasi Belajar Siswa SD Kelas IV dan $V$ Peserta Homeschooling. Sripsi Fakultas Pikologi, Universitas Indonesia. Tersedia pada http://www.lib.ui.ac.id/naskahringkas/2017-04/S57210-Ambar\%20Rah magari. Diakses tanggal 20 Januari 2018.

Setyosari, Punaji. 2012. Metode Penelitian Pendidikan dan Pengembangan. Jakarta: Prenada Media Group.

Setyosari, Punaji. 2015. Metode Penelitian Pendidikan dan Pengembangan. Jakarta: Prenadamedia Group.

Setyowati, Yeni. 2013. "Pengaruh Motivasi dan Tanggung Jawab Belajar Siswa Terhadap Prestasi Belajar Matematika Pada Siswa Kelas VIII SMP Negeri 3 Sragen Tahun Ajaran 2012/2013”. Skripsi Fakultas Keguruan dan Ilmu Pendidikan, Universitas Muhammadiyah Surakarta. Tersedia pada http://eprints.ums.ac.id/19459/. Diakses tanggal 20 Januari 2018.

Sugiyono, 2016. Metode Penelitian Pendekatan Kuantitatif, Kualitatif, dan R\&D. Bandung: Alfabeta.

Sukardi, 2012. Metodologi Penelitian Pendidikan. Jakarta: PT Bumi Aksara.

Supardi, 2015. Penilaian Autentik Pembelajaran Aktif, Kognitif, dan Psikomotor. Jakarta: Raja Grafindo Persada.

Supardi, 2016. Aplikasi Statistika Dalam Penelitian Edisi Revisi. Jakarta Selatan: Change Publication.

Suryanto, dkk. 2014. Evaluasi pembelajaran di SD. Tangerang: Universitas Terbuka.

Susanto, Ahmad. 2013. Teori Belajar dan Pembelajaran di Sekolah Dasar. Jakarta: Kencana.

Trianto, 2010. Model Pembelajaran Terpadu Konsep, Strategi, dan Implementasinya dalam Kurikulum Tingkat Satuan Pendidikan (KTSP). Jakarta : Bumi Aksara.

Widodo, A. 2005. Taksonomi Tujuan Pembelajaran. Jurnal. Bandung: FPMIPA Universitas Pendidikan $\begin{array}{lllll}\text { Indonesia } & \text { Vol. } & 4 & \text { (2). } & \text { Tersedia }\end{array}$ http://file.upi.edu/Direktori/FPMIPA/JUR__PEND._BIOLOGI/196705271992031-

ARI_WIDOD0/2005-Revisi_Taksonomi_Bloom-Didaktis. pdf. Diakses tanggal 1 Maret 2018.

Yaumi, Muhammad. 2014. Pendidikan Karakter Landasan, Pilar, dan Implementasi. Jakarta: Kencana.

Zimmerman, Barry J. 2005. "Homework Practices and Academic Achievment: The Mediating Role Of SelfEfficacy and Perceived Responsibility Beliefs". Skripsi Educational. 